\title{
Sensitisation Study of Normalized 316L Stainless Steel
}

\author{
P. Atanda ${ }^{1}$, A. Fatudimu ${ }^{1}$ and O. Oluwole ${ }^{2 *}$ \\ ${ }^{1}$ Materials Science and Engineering Department, Obafemi Awolowo University,Ile-ife,Nigeria. \\ ${ }^{2}$ Mechanical Engineering Dept, University of Ibadan \\ *Corresponding author: oluwoleo2@asme.org
}

\begin{abstract}
Austenitic stainless steels with excellent corrosion resistance and good weldability have wide applications in industry. These iron-based alloys contain a high level of chromium which form protective oxide film on the surface hence resisting corrosion. The oxide film regenerates when damaged, making the steel 'stainless'. However, carbide precipitation due to a welding process or heat treatment can cause the occurrence of chromium-depleted zones at the boundaries, leading to a phenomenon known as sensitisation, in which the depleted zones become the focus of the intense corrosion.

The present work was concerned with the study of the sensitization and desensitisation of 316L steel at the normalizing temperatures of 750-950 $\mathrm{C}$ and soaking times of 0.5, 1, 2 and $8 \mathrm{hrs}$.

316L stainless steel was observed to be sensitized when heated to $750-850^{\circ} \mathrm{C}$ and held for short soaking times of 0.5 - 2hrs before normalizing. Increasing soaking times at these temperatures to $8 \mathrm{hrs}$ triggered the desensitization process which was fully accomplished at $750^{\circ} \mathrm{C}$ but ongoing at 800 and $850^{\circ} \mathrm{C}$. At $900^{\circ} \mathrm{C}$, sensitization did not occur at 30 mins soaking time but observed at soaking times of 1 and 2hrs. At a longer soaking time of $8 \mathrm{hrs}$, there was full desensitization. At $950^{\circ} \mathrm{C}$, sensitization was already observed at 30 mins. Soaking time and desensitization was observed to be in progress at 1 and 2 hrs soaking time. By 8 hrs there was full desensitization. Thus it was observed that at $950^{\circ} \mathrm{C}$, diffusion of $\mathrm{Cr}$ was thermally aided making desensitization fast. The hardness of normalized 316L stainless steel was also observed to decrease with soaking time and normalization temperature.
\end{abstract}

Key words: Sensitisation; Normalization treatment; 316L Stainless steel 


\section{INTRODUCTION}

The basic 18Cr8Ni (18/8) austenitic stainless steel is so widely used that it accounts for about $50 \%$ of all stainless steel production. The stainless character occurs when the concentration of chromium exceeds about $12 \mathrm{wt} \%$, whereas higher chromium concentrations and the judicious use of other solutes such as molybdenum, nickel and nitrogen is then needed to ensure a robust material $^{1-3}$.

The "L" grades are used to provide extra corrosion resistance after welding. The letter $\mathrm{L}$ after a stainless steel type indicates low carbon (as in 316L). The carbon content is kept to $0.03 \%$ or less to avoid grain boundary precipitation of chromium carbide in the critical range (430 to $900^{\circ} \mathrm{C}$ ). Grain boundary precipitation deprives the steel of the chromium in solution and promotes corrosion adjacent to grain boundaries. By controlling the amount of carbon, this is minimized ${ }^{4-6}$. Chromium is, of course, the primary element for forming the passive film (i.e. high-temperature, corrosion-resistance chromium oxide). Other elements can influence the effectiveness of chromium in forming or maintaining the film, but no other element can, by itself, create the stainless steel.

Nickel in sufficient quantities, is used to stabilize the austenitic phase and to produce austenitic stainless steels ${ }^{3}$. A corrosion benefit is obtained as well, especially in reducing environments. Nickel is particularly useful in promoting increased resistance to mineral acids. When nickel is increased to about 8 to $10 \%$ this is a level required to ensure austenitic structures in a stainless steel that has about $18 \%$ chromium.

Molybdenum in moderate amounts in combination with chromium is very effective in terms of stabilizing the passive film in the presence of chlorides.

Molybdenum is especially effective in enhancing the resistance to pitting and crevice corrosion ${ }^{4}$. Nitrogen is beneficial to austenitic stainless in that it enhances pitting resistance, retards formation of sigma phase. The change in the microstructure of an alloy can be achieved by heat treatment.

\section{MATERIALS AND METHOD}

\subsection{Materials}

316L stainless steel was obtained from the market for the purpose of this experimentation.

\subsection{Methods}




\subsubsection{Heat treatment}

Normalization heat treatments were performed on the samples by varying the temperature and the soaking period. The following temperatures were used: 750, 800, 850, 900 and $950^{\circ} \mathrm{C}$. The different soaking times at these temperatures were 30 mins, 1 hour, 2 hours and 8 hours.

\subsubsection{Mounting and grinding}

First, each specimen was mounted on thermosetting plastic for ease of grinding and polishing. The grinding of the specimens was done on silicon carbide paper ${ }^{7-12}$. The surface of the papers was flushed by a current of water, which serves not only as a lubricant in grinding, but also carries away coarse emery particles, which might otherwise scratch the surface of the specimen. The silicon carbide papers used in achieving the proper grinding of the specimen were in the following grades 120, 240, 320 and 400 grits, grinding respectively in that order of grades.

\subsubsection{Polishing}

The polishing was done on polishing cloth using alumina powder dissolved in water at a reasonable proportion. The alumina powder was of the grade 1 micron and 0.3 micron respectively. Light pressure was applied until the surfaces were free of scratches ${ }^{7-12}$. The samples were cleaned, dried and then examined under the microscope, using a magnification between 50 and 100 so as to check whether the samples were free of scratches.

\subsubsection{Etching}

After polishing, the samples were etched with $5 \mathrm{gm}$ of $\mathrm{FeCl}_{3}+10 \mathrm{ml}$ of $\mathrm{HCl}+50 \mathrm{ml}$ of $\mathrm{H}_{2} \mathrm{O}^{7-12}$. To etch these specimens, they were washed free of any adhering polishing compound and plunged into the etching solution, agitated vigorously for 3 minutes. The specimens were then very quickly transferred to running water, in order to wash away the etchant as rapidly as possible. It was then examined with the naked eye, to see to what extent etching has taken place. The successfully etched surface appeared dull.

After this, the specimens were observed under optical microscope and photomicrographs taken.

\section{RESULTS AND DISCUSSIONS}

\subsection{Results}

The photomicrographs of the normalized specimens are shown in Figs. 1 - 5. Figs 1a-d show the photomicrographs of the normalized specimens from $750^{\circ} \mathrm{C}$ each held at the soaking 
temperature for 30 mins, $1 \mathrm{hr}$, $2 \mathrm{hrs}$ and $8 \mathrm{hrs}$ respectively. Chromium depleted zones could be seen here but negligible in the sample soaked for $8 \mathrm{hrs}$.

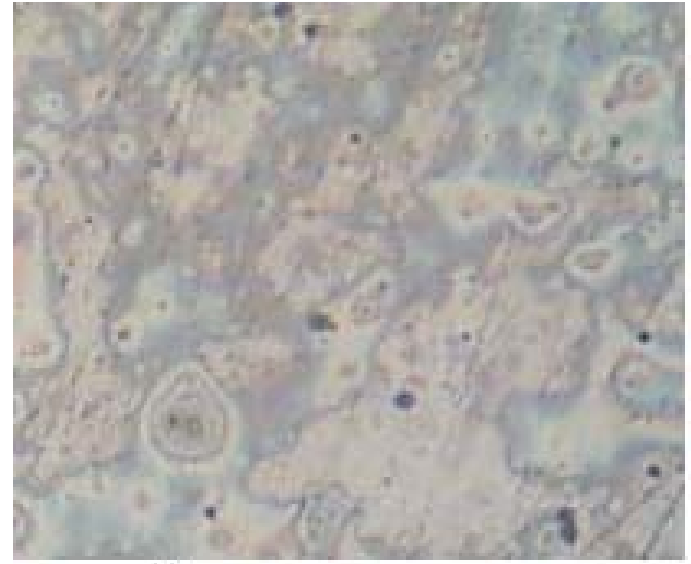

$750^{\circ} \mathrm{C}$ held for 30 mins

(a)

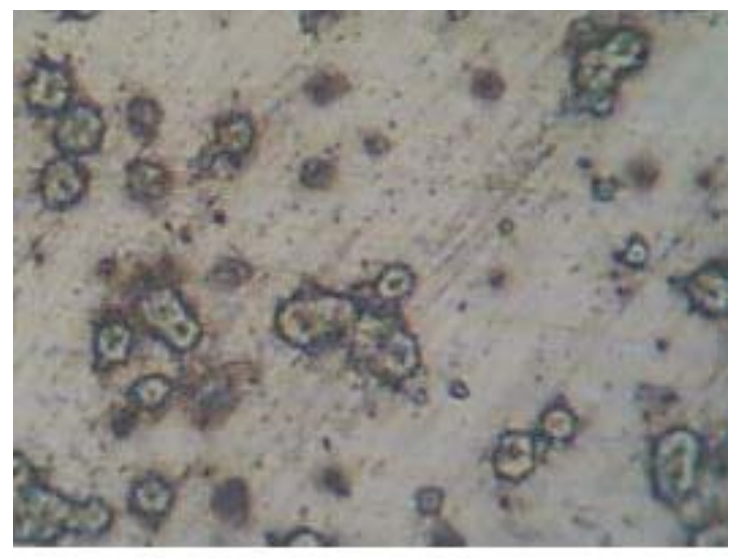

$750^{\circ} \mathrm{C}$ treated for 2 hours

(c)

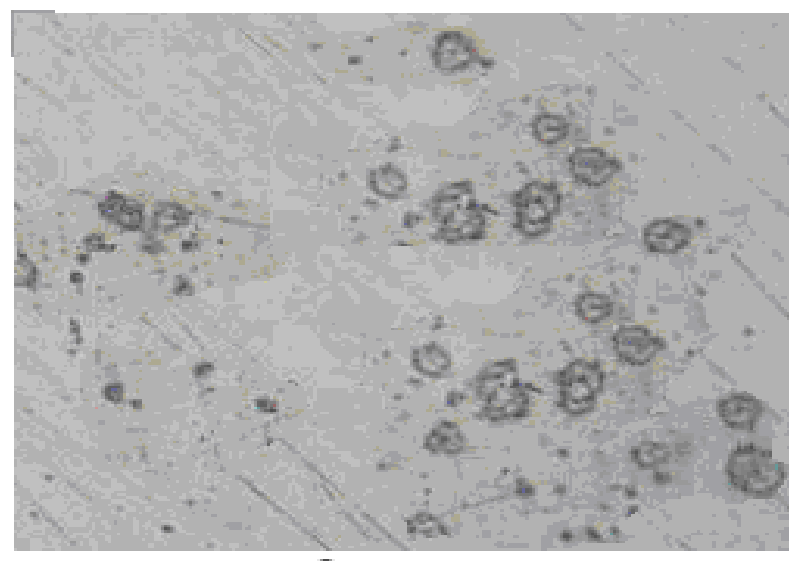

$750^{\circ} \mathrm{C}$ held for $\mathrm{hr}$

(b)

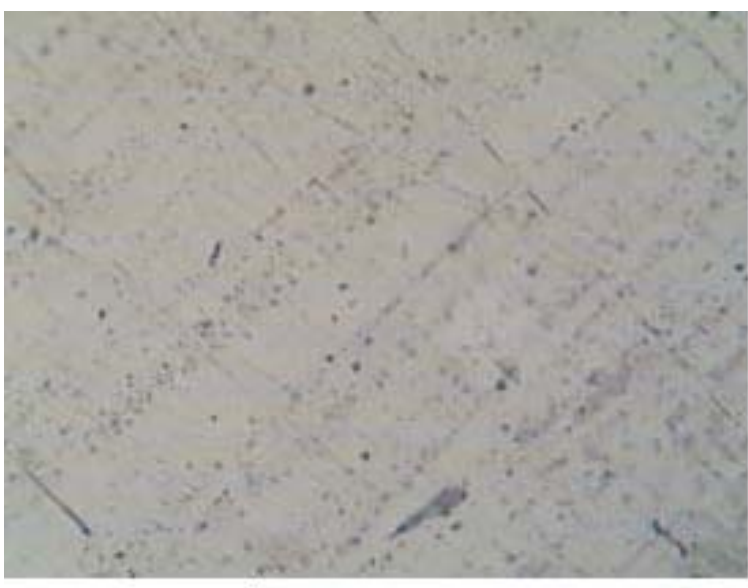

$750^{\circ} \mathrm{C}$ held for $8 \mathrm{hrs}$

(d)

Figures 1. (a) Sample heated to $750^{\circ} \mathrm{C}$ held for $30 \mathrm{mins}$, (b) Sample heated to $750^{\circ} \mathrm{C}$ held for $1 \mathrm{hr}$, (c) Sample heated to $750{ }^{\circ} \mathrm{C}$ held for $2 \mathrm{hrs}$ (d) Sample heated to $750{ }^{\circ} \mathrm{C}$ held for $8 \mathrm{hrs}$. 
Figs 2a-d show the photomicrographs of the normalized specimens from $800^{\circ} \mathrm{C}$ each held at the soaking temperature for $30 \mathrm{mins}, 1 \mathrm{hr}, 2 \mathrm{hrs}$ and $8 \mathrm{hrs}$ respectively. Chromium depleted zones could also be seen here and apparently very slightly manifested as well in the sample soaked for 8hrs.

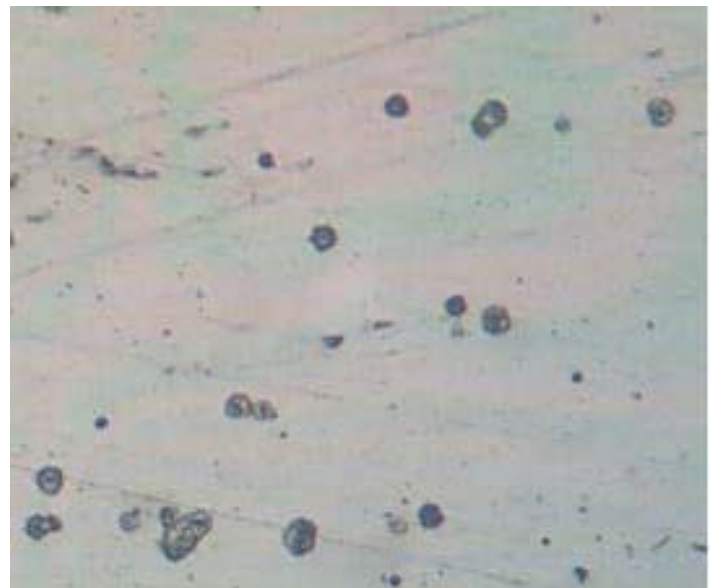

$800^{\circ} \mathrm{C}$ held for $30 \mathrm{mins}$

(a)

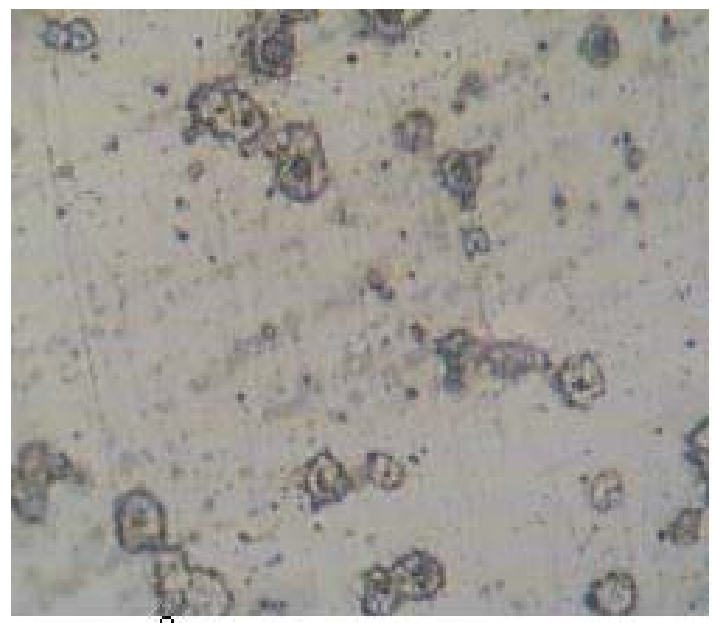

$800^{\circ} \mathrm{C}$ held for 2 hours

(c)

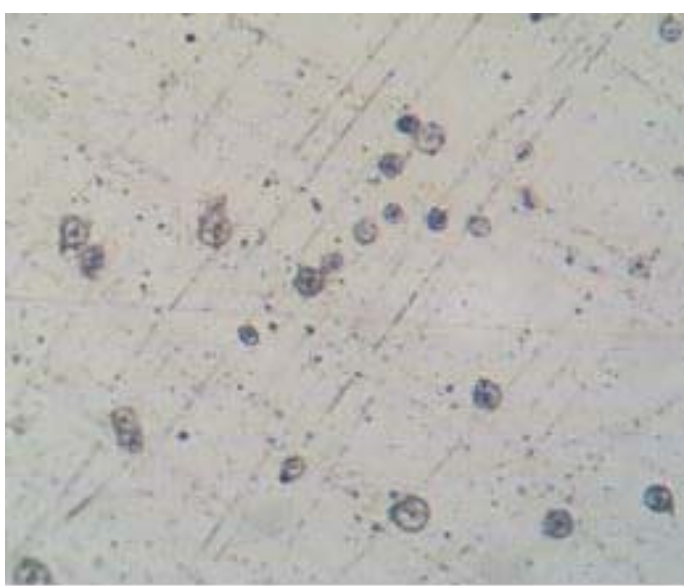

$800^{\circ} \mathrm{C}$ held for 1 hour

(b)

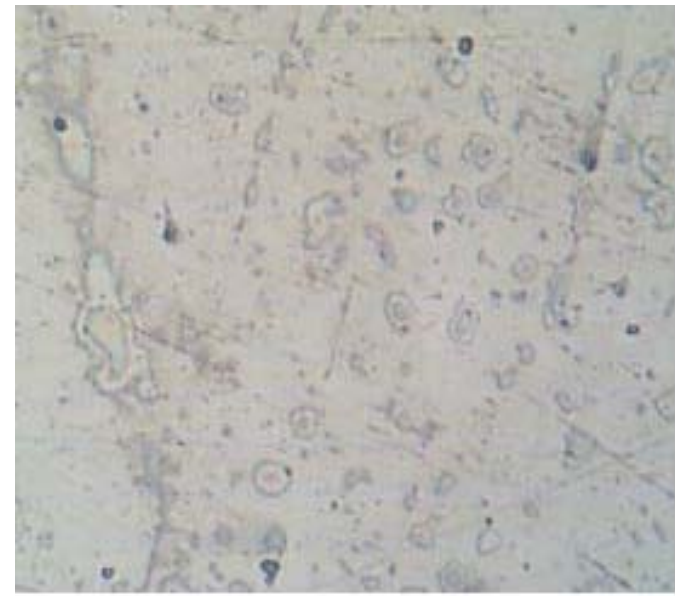

$800^{\circ} \mathrm{C}$ held for 8 hours

(d)

Figures 2. (a) Sample heateed to $800{ }^{\circ} \mathrm{C}$ held for 30mins, (b) Sample heated to $800{ }^{\circ} \mathrm{C}$ held for $1 \mathrm{hr}$, (c) Sample heated to $800^{\circ} \mathrm{C}$ held for $2 \mathrm{hrs}$ (d) Sample heated to $800^{\circ} \mathrm{C}$ held for $8 \mathrm{hrs}$. 
Figs 3a-d show the photomicrographs of the normalized specimens from $850^{\circ} \mathrm{C}$ each held at the soaking temperature for $30 \mathrm{mins}, 1 \mathrm{hr}, 2 \mathrm{hrs}$ and $8 \mathrm{hrs}$ respectively. Chromium depleted zones could be seen here as well but also increasingly well formed in the sample soaked for 8hrs.

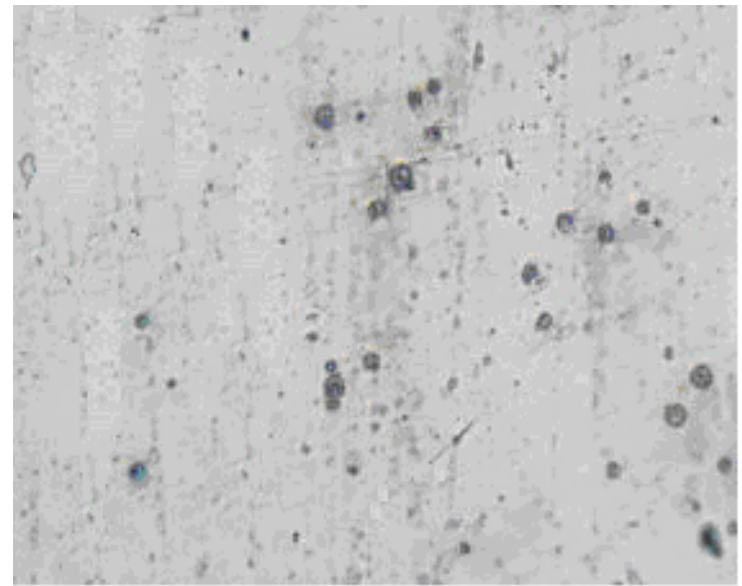

$850^{\circ} \mathrm{C}$ held for 30 minutes

(a)

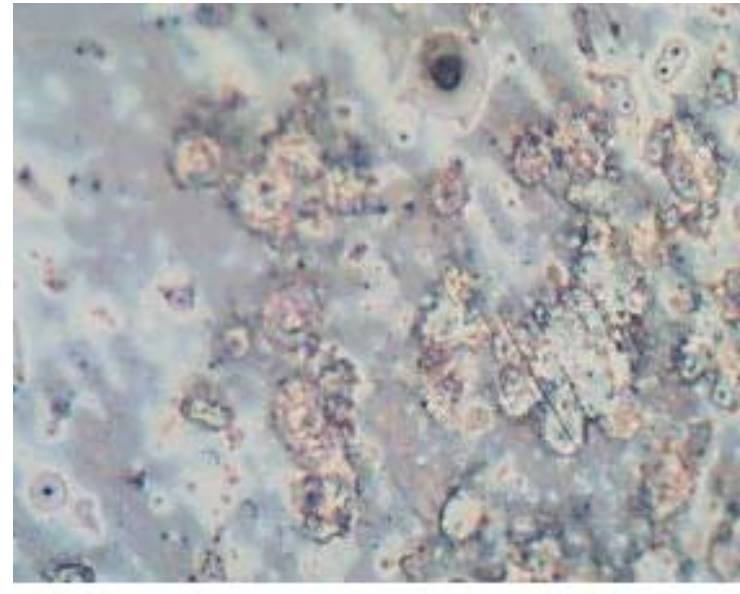

$850 \mathrm{C}$ held for 2 hours

(c)

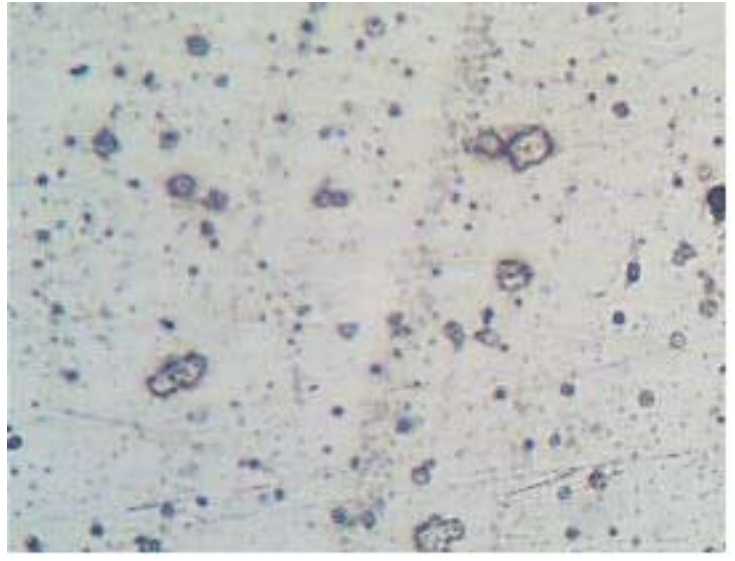

$850^{\circ} \mathrm{C}$ held for 1 hour

(b)

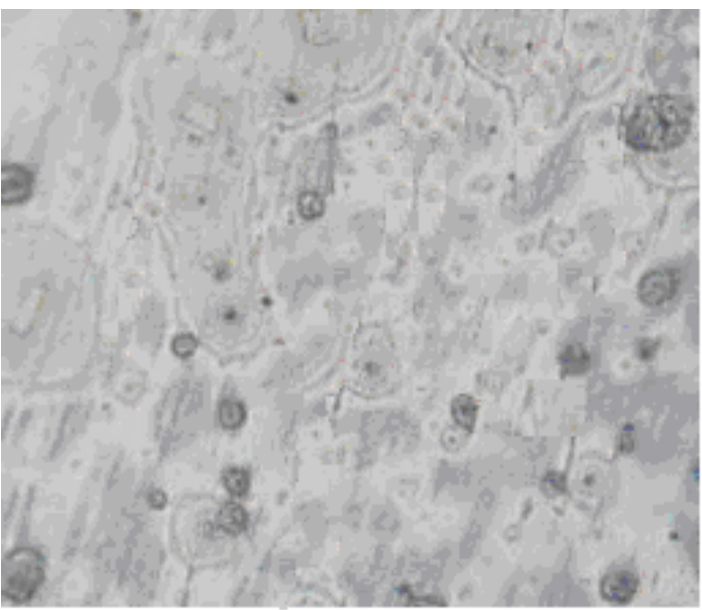

$850^{\circ} \mathrm{C}$ held for 8 hours

(d)

Figures 3. (a) Sample heated to $850{ }^{\circ} \mathrm{C}$ held for 30mins, (b) Sample heated to $850^{\circ} \mathrm{C}$ held for $1 \mathrm{hr}$, (c) Sample heated to $850{ }^{\circ} \mathrm{C}$ held for $2 \mathrm{hrs}$ (d) Sample heated to $850{ }^{\circ} \mathrm{C}$ held for $8 \mathrm{hrs}$. 
Figs 4a-d show the photomicrographs of the normalized specimens from $900^{\circ} \mathrm{C}$ each held at the soaking temperature for $30 \mathrm{mins}, 1 \mathrm{hr}, 2 \mathrm{hrs}$ and $8 \mathrm{hrs}$ respectively. Chromium depleted zones could be seen only in samples $4 \mathrm{~b}$ and $4 \mathrm{c}$ but absent in the sample soaked for $8 \mathrm{hrs}$ and 30 mins.

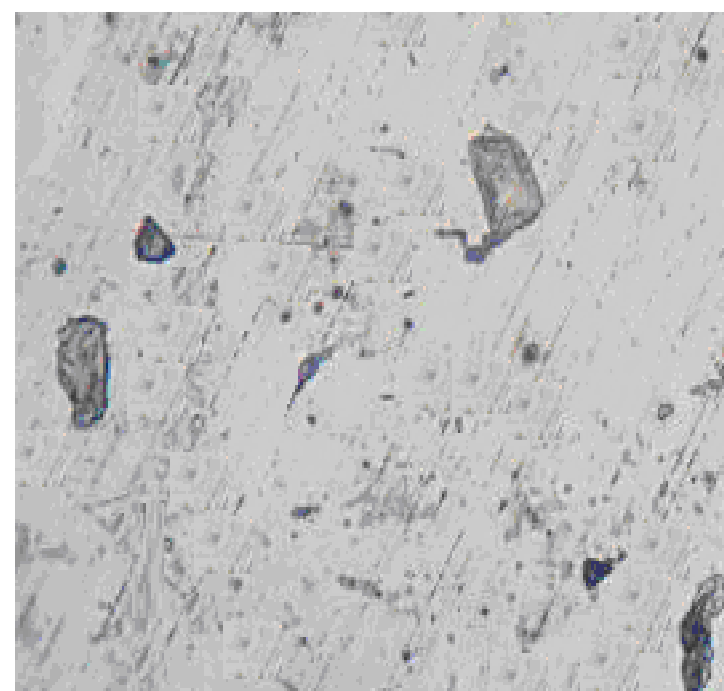

$900^{\circ} \mathrm{C}$ held for 30 minutes

(a)

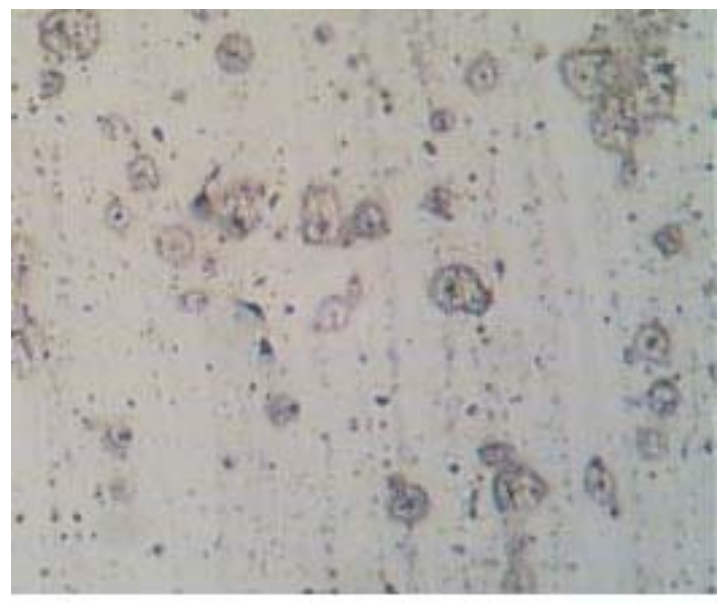

$900^{\circ} \mathrm{C}$ held for 2 hours

(c)

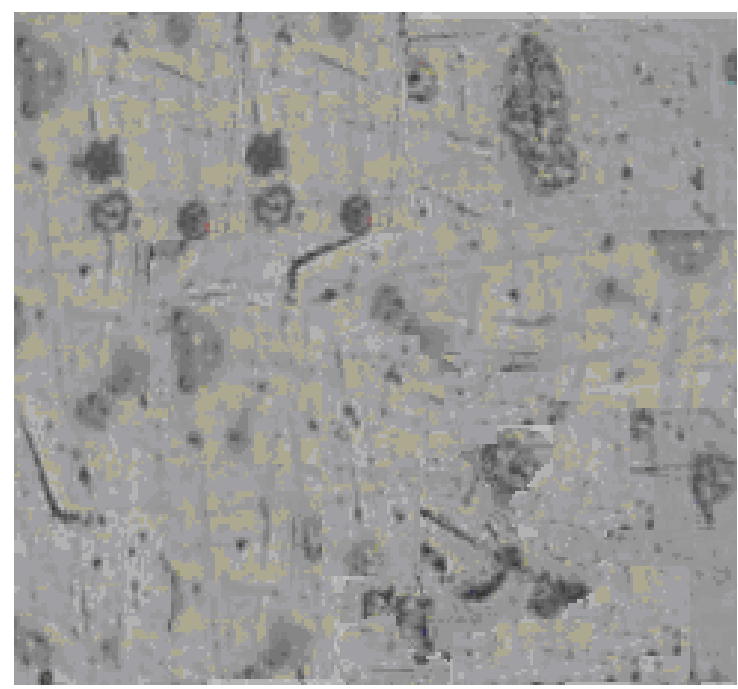

$900^{\circ} \mathrm{C}$ held for 1 hours

(b)

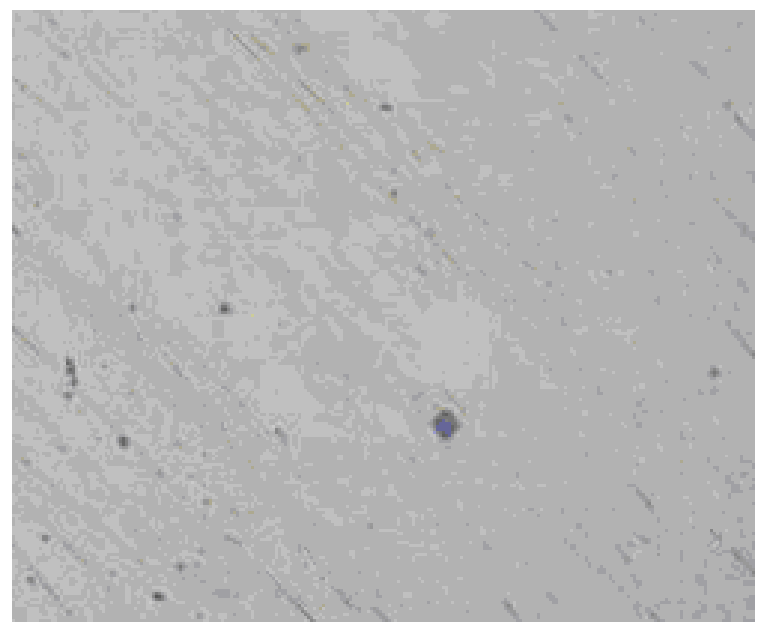

$900^{\circ} \mathrm{C}$ held for 8 hours

(d)

Figures 4. (a) Sample heated to $900{ }^{\circ} \mathrm{C}$ held for 30mins, (b) Sample heated to $900{ }^{\circ} \mathrm{C}$ held for $1 \mathrm{hr}$, (c) Sample heated to $900{ }^{\circ} \mathrm{C}$ held for $2 \mathrm{hrs}$ (d) Sample heated to $900^{\circ} \mathrm{C}$ held for $8 \mathrm{hrs}$. 
Figs 5a-d show the photomicrographs of the normalized specimens from $950^{\circ} \mathrm{C}$ each held at the soaking temperature for $30 \mathrm{mins}, 1 \mathrm{hr}$, $2 \mathrm{hrs}$ and $8 \mathrm{hrs}$ respectively. Chromium depleted zones are negligible in all the specimens here and could be seen to be observed faintly only in $4 \mathrm{~b}$ and c which correspond to short soaking times of 1and 2 hrs respectively.

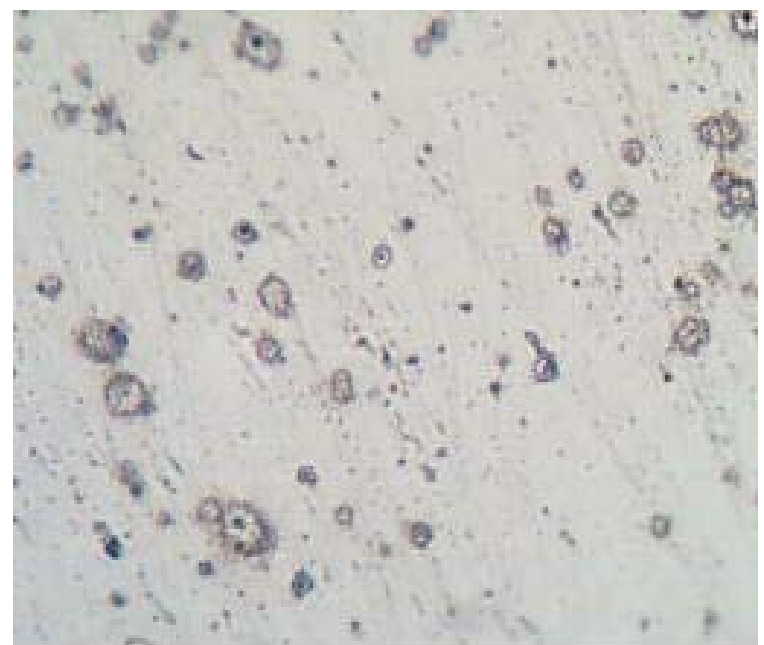

$950^{\circ} \mathrm{C}$ held for 30 minutes

(a)
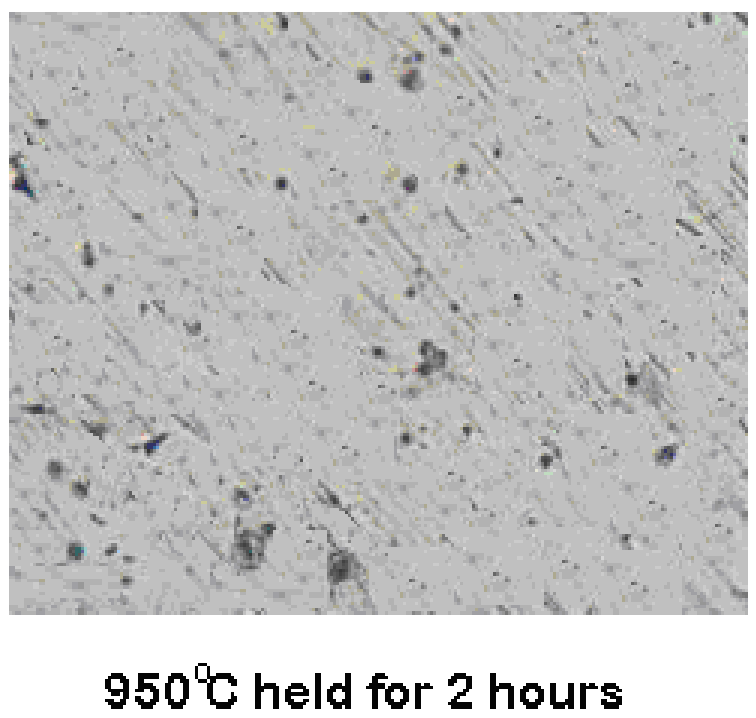

(c)

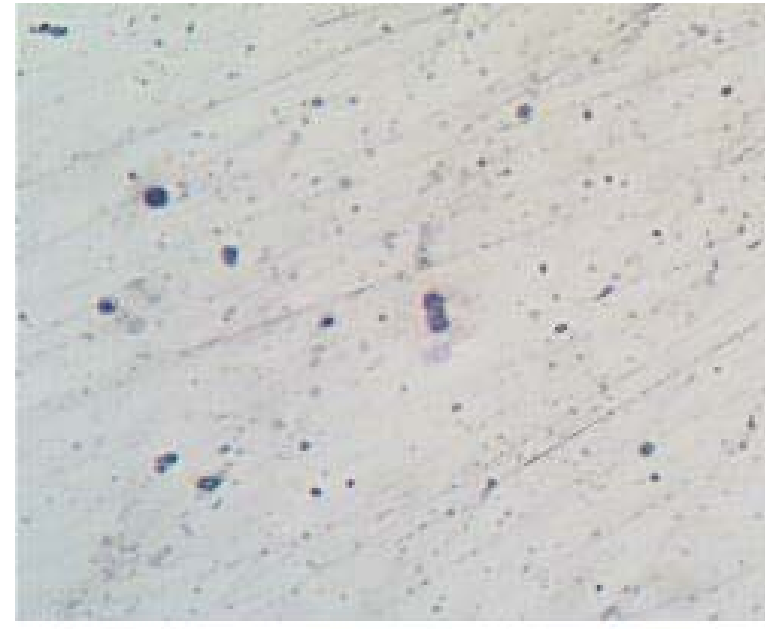

$950^{\circ} \mathrm{C}$ held for 1 hour

(b)

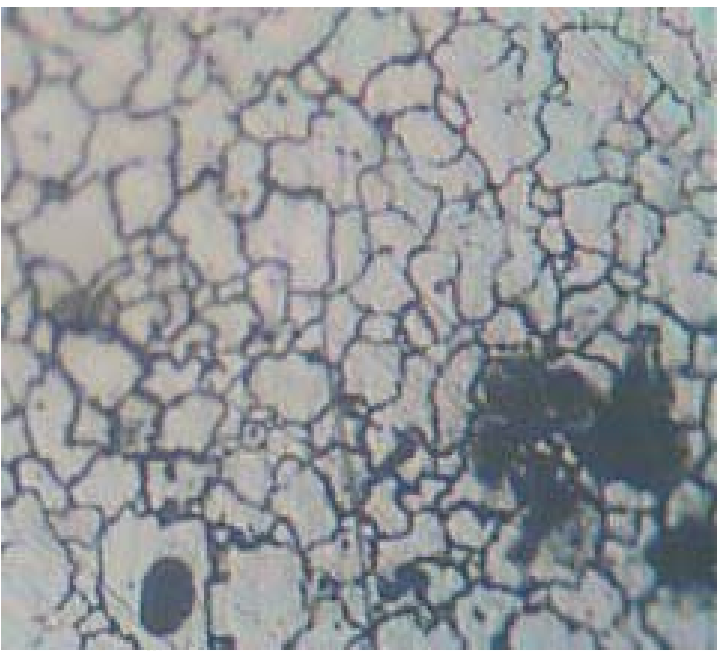

$950^{\circ} \mathrm{C}$ held for 8 hours

(d)

Figures 5. (a) Sample heated to $950^{\circ} \mathrm{C}$ held for $30 \mathrm{mins}$, (b) Sample heated to $950{ }^{\circ} \mathrm{C}$ held for $1 \mathrm{hr}$, (c) Sample heated to $950{ }^{\circ} \mathrm{C}$ held for $2 \mathrm{hrs}$ (d) Sample heated to $950{ }^{\circ} \mathrm{C}$ held for $8 \mathrm{hrs}$.

Figure 6 shows the micrograph of the untreated sample. 


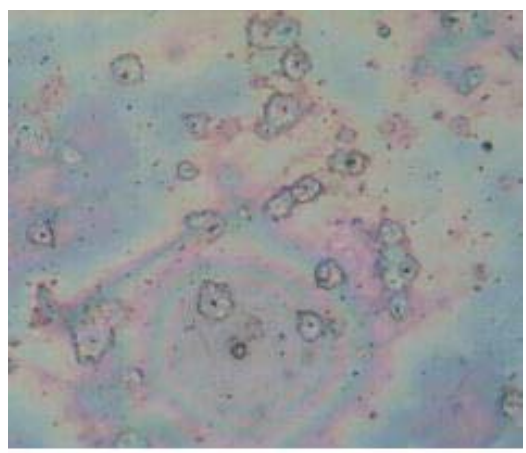

untreated Sample

Figure 6. Untreated Sample.

The photomicrostructures of these heat treated austenitic steel samples have been show a clear cut difference between the treatment using long time ( 8 hours) and short times $(0.5 \mathrm{hr}, 1 \mathrm{hr}$ and $2 \mathrm{hrs}$ ). The chromium depleted zones increased considerably up to the 2 hours treatment but reduced on the samples soaked for 8 hrs. The Rockwell hardness of some of the samples is presented in Table 1 and Fig. 7.

Table 1. Brinnel Hardness of some Samples.

\begin{tabular}{|l|l|l|}
\hline S/N & SAMPLES & HARDNESS, $\mathbf{H}_{\mathbf{B}}$ \\
\hline 1 & Untreated Sample & 187 \\
\hline 2 & $750^{\circ} \mathrm{C}$ held for 30mins & 169 \\
\hline 3 & $750^{\circ} \mathrm{C}$ held for $1 \mathrm{hr}$ & 167 \\
\hline 4 & $750^{\circ} \mathrm{C}$ held for $2 \mathrm{hrs}$ & 167 \\
\hline 5 & $750^{\circ} \mathrm{C}$ held for $8 \mathrm{hrs}$ & 166 \\
\hline 6 & $800^{\circ} \mathrm{C}$ held for 30mins & 164 \\
\hline 7 & $800^{\circ} \mathrm{C}$ held for $1 \mathrm{hr}$ & 163 \\
\hline 8 & $800^{\circ} \mathrm{C}$ held for $2 \mathrm{hrs}$ & 163 \\
\hline 9 & $800^{\circ} \mathrm{C}$ held for $8 \mathrm{hrs}$ & 161 \\
\hline 10 & $850^{\circ} \mathrm{C}$ held for 30mins & 156 \\
\hline 11 & $850^{\circ} \mathrm{C}$ held for $1 \mathrm{hr}$ & 152 \\
\hline 12 & $850^{\circ} \mathrm{C}$ held for $2 \mathrm{hrs}$ & 149 \\
\hline 13 & $850^{\circ} \mathrm{C}$ held for $8 \mathrm{hrs}$ & 143 \\
\hline 14 & $900^{\circ} \mathrm{C}$ held for $30 \mathrm{mins}$ & 131 \\
\hline 15 & $900^{\circ} \mathrm{C}$ held for $1 \mathrm{hr}$ & 115 \\
\hline 16 & $900^{\circ} \mathrm{C}$ held for $2 \mathrm{hrs}$ & 111 \\
\hline 17 & $900^{\circ} \mathrm{C}$ held for $8 \mathrm{hrs}$ & 110 \\
\hline 18 & $950^{\circ} \mathrm{C}$ held for $30 \mathrm{mins}$ & 109 \\
\hline 19 & $950^{\circ} \mathrm{C}$ held for $1 \mathrm{hr}$ & 107 \\
\hline 20 & $950^{\circ} \mathrm{C}$ held for $2 \mathrm{hrs}$ & 99 \\
\hline
\end{tabular}




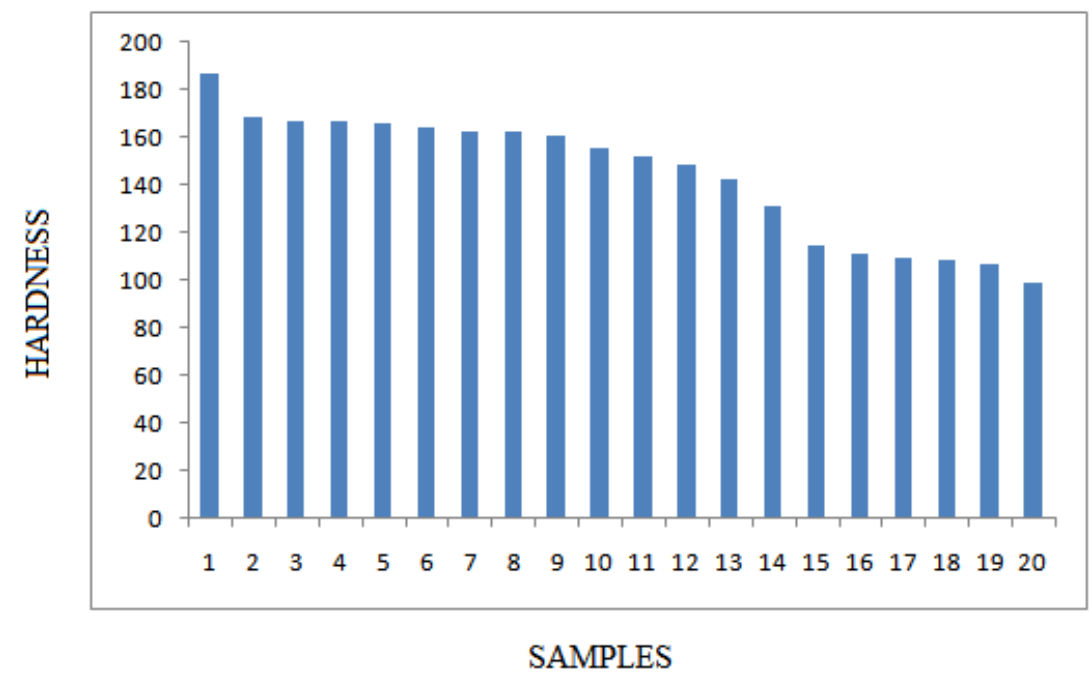

Fig. 7. Comparative Brinnel Hardness chart of samples in Table1.

\subsection{Discussions}

From the microstructures observed in Figs. 1a-c, 2a-c, 3a-c, 4a-c and 5a-c, the black patches form the depleted - zone. It could be observed that the width of the depleted zone increased with time, leading to a flatter chromium profile near the grain boundaries at the soaking temperatures of $750-850^{\circ} \mathrm{C}$ and for short soaking times of 30 mins to $2 \mathrm{hrs}$. This heat treatment procedure had significant effect on the chromium concentration profile. The process of short time heat treatment brought about sensitization (the breakdown in corrosion resistance which occurs when austenitic stainless steels are reheated in the temperature range $550{ }^{\circ} \mathrm{C}$ to $850{ }^{\circ} \mathrm{C}$ ). Sensitisation is associated with the precipitation of the chromium- rich carbide such as $\mathrm{Cr}_{23} \mathrm{C}_{6}$ or $\mathrm{Cr}_{7} \mathrm{C}_{3}$ along the grain boundaries. During the carbide precipitation, interstitial carbon diffuses rapidly to the grain boundaries. However, chromium diffusion which is much more slower, resulted in the chromium - depleted zones at the grain boundaries. In this state the steel is susceptible to intergranular corrosion.

Figs 4 and 5 show a self - healing processs (desensitization) already taken place, refering to the return of corrosion resistance of the stainless steels after prolonged heat treatment in the temperature range which initially caused sensitization. Self - healing began when the chromium content at the carbide -matrix interface increased due to chromium diffusion from the matrix further away from the grain boundary. Thus, prolonged soaking at 900 and $950^{\circ} \mathrm{C}$ did not have a deleterious effect on 316L stainless steel. The hardness of the samples was also observed to decrease with increase in temperature (Fig. 7). 


\section{CONCLUSION}

316L stainless steel was observed to go into sensitization when heated to $750-850^{\circ} \mathrm{C}$ and held for short soaking times of $0.5-2$ hrs before normalizing. Incresing the soaking times at this temperatures triggered desensitization process which was fully accomplished at $750^{\circ} \mathrm{C}$ but ongoing at 800 and $850^{\circ} \mathrm{C}$. At $900^{\circ} \mathrm{C}$, sensitization was observed at soaking times of 1 and 2 hrs before normalizing. At a longer soaking time of 8 hrs before normalization, there was full desensitization. At $950^{\circ} \mathrm{C}$, sensitization was already observed at 30 mins soaking time and desensitization was observed to be in progress at 1 and 2 hrs soaking time. By 8 hrs there was full desensitization of 316L stainless steel. Thus it was observed that at $950^{\circ} \mathrm{C}$, the diffusion of $\mathrm{Cr}$ was thermally aided making it very fast and initial sensitisation was cancelled out. The hardness of normalized 316L stainless steel was also observed to decrease with soaking time and normalization temperature.

\section{REFERENCES}

[1] Howard, O.T. and Leonard, W.A. (1963). 'An Introduction to Stainless Steel' New York.

[2] Lacombe P., Baroux B., and Beranger G., editors. (1993) 'Stainless steel' The Journal of Physics.

[3] Parr J.G. and Hanson A.(1965) 'An Introduction to Stainless Steel' American Society For Metals.

[4] Gooch T. G and Willingham D.C.(1975) 'Weld Decay in Austenitic Stainless Steel’, Welding Institute, Cambridge, United Kingdom.

[5] Honeycombe R. W. K. and Bhadeshia H. K. D. H.(1995) 'Steels-microstructure and properties'. Edward Arnold, 2nd edition.

[6] Kirkaldy J. S and Young D.J.(1987) 'Diffusion in the Condensed State'. Institute of Metals, London.

[7] Brandon, D. G.(1966) 'Modern Techniques in Metallography'. Butterworths, London.

[8] Greaves, R. H. \& H. Wrighton Practical Microscopical Metallography (4th Edition). Chapman and Hall, London. 1960

[9] Fawole, M.O. and Oso, B.A (2001). The Principles of Metallographic Laboratory Practice. Spectrum Books Ltd, Ibadan, Nigeria.

[10] Fujita N. and Bhadeshia H. K. D. H. Mater. Sci. Tech., 15: 627 - 634, 1999.

[11] Hughes, K.V.(1994) Practical Microscopical Metallography. University of Missouri Extension, Columbia Publication.

[12] Kehl, G. L. (1949) 'The Principles of Metallographic Laboratory Practice’. (3rd edition). McGraw-Hill, New York, Toronto, London. 